\title{
THE ROLE OF SPECIAL EVENT IN ATTRACTING MUSEUM VISITORS AND POPULARIZING MUSEUMS
}

\author{
Tanja Komarac \\ Đurđana Ozretić Došen \\ Vesna Jurić Bulatović
}

https://doi.org/10.20867/tosee.05.38

\begin{abstract}
Purpose - This paper aims to address and analyze the role which special event (more specifically "The Night of Museums") has in promoting and increasing museum visitation, and consequently in changing attitude towards museums among visitors. This is especially challenging in Eastern European Countries (like Croatia) where the majority of population "avoids" museums. Only $35 \%$ of Croatian citizens visited museums (in 2017), which is below EU 28 average of 50\%. Some reasons are related to the rise of popularity of different forms of entertainment in cultural and creative industries, but also with ignoring market needs. Domestic visitors represent a potentially important market for the first-time and repeat visitations, which need to be explored. A special event can be crucial in promoting museums and creating positive change in a society by changing attitudes towards museums as a part of tourism and destination offer.

Methodology - The paper uses qualitative methodology, with the aim of obtaining insights into role of special events ("The Night of Museums") for popularizing museums. In-depth interviews with five museum professionals responsible for organizing "The Night of Museums" events were conducted. To gain additional insights into the research problem, web and social media mentions of two official hashtags (\#nocmuzeja and \#nocmuzeja2019) were tracked in a period of about one month.

Findings - Results of the in-depth interviews show that organizing "The Night of Museums" event is often a very challenging task because of security issues, museums' physical limitations and lack of expert personnel. Managers also worry about how hundreds or even thousands of visitors can easily "consume" museum experience. If appropriately organized, a special event can help museums to reach better their domestic audience, because it contributes to higher visibility of museums and their popularity. Majority of museums offers additional programs for "The Night of Museums" event. Additionally, the results of the analysis of web and social media mentions show an increase mentioning of "The Night of Museums" event during the days around the event. Surprisingly, results show that the most important channel for "The Night of Museums" event is predominantly - Instagram.

Contribution - To our knowledge, this paper is the first that analyses the role of the special event ("The Night of Museums") from the perspective of museum professionals. It demonstrates the importance of the event in popularization of museum visitation in the frame of the tourism activities of domestic visitors, which might be practiced throughout the year, regardless of the tourist season. Also, we prove that special events like "The Night of Museums" can be a powerful tool in creating positive change in society, by changing habits of museum visitation.
\end{abstract}

Keywords museums, special event, "The Night of Museums", qualitative research, Croatia 
ToSEE - Tourism in Southern and Eastern Europe, Vol. 5, pp. 375-387, 2019

T. Komarac, Đ. Ozretić Došen, V. Jurić Bulatović: THE ROLE OF SPECIAL EVENT IN ATTRACTING ...

\section{INTRODUCTION}

Recent data from the European Commission on heritage site visitation in EU countries shows quite large differences between Eastern and Western European member countries. In Eastern European countries, like Croatia, the majority of the population "avoids" museums. Only $35 \%$ of Croatian citizens visited museums in 2017 , which is below EU 28 average of $50 \%$. Also, only $21 \%$ of Croatian citizens are regular visitors of museums, galleries, monuments, festivals or concerts (below EU 28 average, too, which is $31 \%$ ) (European Commission, 2018). This data signals to problems existing in Croatian museum sector for attracting and popularising museums.

In order to attract visitors, museums increasingly organise different forms of special events (Axelsen, 2006; Germain, 2016), with more and more events organised by night (Germain, 2016). One of the most popular special events organised in nocturnal context is "The Night of Museums". Several previous studies provide some evidence that this special event contributes to the higher museum visitation in Eastern European countries: in Croatia (Noć muzeja, 2018; Mavrin and Glavaš, 2014), Serbia (Bjeljac et al., 2011), Romania (Dumbrăveanu et al., 2014), and Poland (Jaremen and Rapacz, 2018).

Taking into consideration the existing studies this paper aims to address and analyze further the role which special event, more specifically "The Night of Museums" has in promoting and increasing museum visitation in Croatia, and consequently in changing attitudes towards museums among visitors. Domestic visitors represent a potentially important market for first-time and repeat visitations that need to be explored. An appropriate special event can be crucial in promoting museums and creating positive change in society by changing attitudes towards museums as a part of tourism and destination offer.

The paper consists of six sections. After the introduction, the second section is dedicated to the theoretical background that deals with special events in the museum sector and related marketing challenges. The short history of "The Night of Museums" event in Croatia follows. In the fourth section methodological approach is described, followed by a presentation of the key results. Research limitations are presented in the fifth section. The paper ends with the discussion and conclusion; several theoretical and practical implications for museum management are included.

\section{THEORETICAL BACKGROUND}

Special events belong to event tourism field which is explored in two connected research areas (1) tourism management and tourism studies and (2) event management and event studies (Getz, 2008). Special event is defined as "a gathering of human beings, generally lasting from few hours to few days, and designed to celebrate, honor, sell, teach about, or observe human endeavors" (Matthews, 2008, 2).

Ever since the budget cuts in the museum sector, museums are forced to attract a wider audience (Goulding, 2000). Special events offered by museums represent interesting potential sources of income generation. Although some types of them, like media events, 
ToSEE - Tourism in Southern and Eastern Europe, Vol. 5, pp. 375-387, 2019

T. Komarac, Đ. Ozretić Došen, V. Jurić Bulatović: THE ROLE OF SPECIAL EVENT IN ATTRACTING ...

do not generate income directly, they form an important part of marketing communication strategy. Also, special events can be community-oriented, used for fundraising (Dumbrăveanu et al., 2014). Special events are sometimes called cultural events (Jareman and Rapacz, 2018) and are used as one of the tools capable to attract a wider museum and non-museum audience (Axelsen, 2006).

New technologies represent powerful tools for attracting museum audience and their proper use represents one of the biggest, current museum management challenges. Social media enables museums to listen, converse and measure responses of their audience (Gallagher and Sowa, 2014 in Hill et al., 2018). The study conducted by Fletcher and Lee (2012) in American museums has revealed that museums increasingly use social media for one-way communication with the aim of reaching larger or newer audiences. In addition, Lazzeretti et al. (2015) have found that social media platforms like Facebook, Twitter and YouTube are often used for the promotion of museums' special events and to enhance visitors' interest for those events.

Current literature (e.g. Axelsen, 2006) shows that there are different forms of special events: 1) opening night events, 2) holiday, seasonal and commemorative events, 3) special programs, 4) workshops and 5) festivals. The first type, night events, has been recognized as particularly attractive to visitors and museum professionals. This is mainly due to the different, unique experience that can be delivered in nocturnal setting (Germain, 2016) and general rise of so called night-time economy in capital cities all over the Europe (Evans, 2012).

Researching the special events at night in the French museum sector, Germain (2016) discovered three types of late openings:

(1) late openings that happen only once or twice a year, (e.g., "The Night of Museums" or "Nuit Blanche"/'Light Events"),

(2) summertime late openings, and

(3) regular night openings which take place during the year.

Research on the first type of special events, late openings which are organized once or twice a year is scarce. Existing studies on "The Night of Museums" are mainly focused on discovering the demographic structure of visitors (e.g. Bjeljac et al., 2011; Dumbrăveanu et al., 2014) and attempt to reveal their motivation for visiting these kinds of events (e.g. Dumbrăveanu et al., 2014). Bjeljac et al. (2011) conducted the study in Serbia and discovered that women visited "The Night of Museums" events more often than men. Also, they discovered that museums with the offer of the entertainment content and exhibitions which were prepared and showed in a different way than usual attracted more young visitors. Authors conclude that "The Night of Museums" has managed to attract a wider audience, i.e. those visitors that do not visit museums often (like the young ones). Similarly, in Romania, Dumbrăveanu et al., $(2014,59)$ discovered that "women and young people were the most interested in attending "The Night of Museums"". Furthermore, their research results show that the working population finds it difficult to visit museums during weekdays, due to the lack of time and short visiting hours. Respondents perceived the price of the museum tickets as being high, which has led to the lack of interest in cultural programs (interestingly, authors points to this finding as a paradox, because the prices were lower than those of cinema tickets). 
ToSEE - Tourism in Southern and Eastern Europe, Vol. 5, pp. 375-387, 2019

T. Komarac, Đ. Ozretić Došen, V. Jurić Bulatović: THE ROLE OF SPECIAL EVENT IN ATTRACTING ...

Although the second type of special night event, known as summertime late openings exists in practice, research on that topic is still non-existing.

Research on the third type, regular night openings is scarcer in comparison to the research on daytime museum visits (Germain, 2016). Germain (2016) has discovered that museum visitors have different expectations from the night visits to museum, which are related primarily to peaceful and relaxed experience (both physically and psychologically).

The existing evidence shows that the visitors' expectations of special events are multiple. They are looking for social experiences, access to experts (e.g. artists), and the opportunity to be involved in hands-on activities. Furthermore, they expect "out of the ordinary" experiences that have an atmosphere of energy and vibrancy (Axelsen, 2006). Besides the social factors, Goulding (2000) pointed out the significance of physical and environmental conditions for museum visitors' experience, that are changing when museum host special events, especially those that are attracting wider audience. Because of special events popularity, where hundreds or even thousands of visitors want to visit the same museum at the same time, problems with physical and environmental factors can occur. More precisely, crowding, seats and noise problems can happen because of the higher number of museum visitors who are trying to "consume" museum service/experience (Goulding, 2000).

\section{THE HISTORY OF “THE NIGHT OF MUSEUMS” IN CROATIA}

Research on museum professionals' opinions in Croatia has discovered that museums are predominantly "old-fashioned" and tend to ignore competition (Komarac et al. 2017). Also, a lack of service orientation was discovered, which signals to the deficiency of museums' marketing orientation.

However, there is an evident and ongoing increase in museums' participation in the special event "The Night of Museums" (traditionally held on the last Friday of January). The number of Croatian cultural institutions (museums, galleries and other cultural institutions) that have participated in "The Night of Museums" event in the period from 2005 to 2017 has increased from 6 institutions in 2005 to 230 institutions in 2017. Also, during the period of the last five years (2013-2017) museums have attracted on average 300000 visitors in only one night - "The Night of Museums" (Noć muzeja, 2018).

Throughout thirteen years of organizing "The Night of Museums", the continuous increase in museum visits had been recorded during the special event (until 2014) and the slow decrease in the last three years (2015-2018) (Noć muzeja, 2018). Secondary data on museum visits shows the visitors' positive opinions towards „The Night of Museums“. During the event, visitors visit on average up to three museums. Furthermore, young visitors (19-35) and women are the most frequent visitors of the special event (Croatian Museum Association Internal document, 2012). 
ToSEE - Tourism in Southern and Eastern Europe, Vol. 5, pp. 375-387, 2019

T. Komarac, Đ. Ozretić Došen, V. Jurić Bulatović: THE ROLE OF SPECIAL EVENT IN ATTRACTING ...

Despite the rising popularity of the special event "The Night of Museums" in Croatia, little is known about its significance for the museum business performance. Up to now, the research on the subject has been quite rare and fails to provide a comprehensive picture of its role. Museum management professionals' opinions about the importance and appropriateness of organizing special events are not known well. Also, museum visitors' motivations and habits for visiting special events are not explored enough yet. Therefore, in order to gain more insights about the role of the special event "The Night of Museums" from the perspective of museum management professionals, the underlying research question of this study is posited (based on the prior evidence and the presented theoretical framework):

RQ: What is the role of special event "The Night of Museums" in attracting museum visitors and popularizing museums?

\section{METHODOLOGY}

Two different studies were carried out aiming to gain more insights and a holistic picture of the role which special event "The Night of Museums" has for Croatian museums.

Museum professionals' opinions about different aspects of "The Night of Museums" were investigated in the exploratory qualitative study, conducted in two phases. The first phase was carried out in 2013 as a part of a larger research project. The second, the much more in-depth phase was a recent one, in 2018-2019. Both times an intentional experts sample was chosen, consisting of museum professionals responsible for organizing the event. Face-to-face in-depth interviews were conducted; the semi-structured interview guides were used, which were prepared based on the theoretical background. Respondents were asked a series of ten open-ended questions. The characteristics of the sample of the recent study (2018-2019) are listed in the Table 1.

\section{Table 1: Sample characteristics}

\begin{tabular}{|l|l|l|l|}
\hline Respondents code & Type of museum (owner) & Designation & Gender \\
\hline M01 & $\begin{array}{l}\text { specialised museum - } \\
\text { history museum } \\
\text { (government) }\end{array}$ & museum educator & Female \\
\hline M02 & $\begin{array}{l}\text { specialised museum -natural } \\
\text { history (government) }\end{array}$ & marketing professional & Male \\
\hline M03 & general museum - (city) & museum director-curator & Female \\
\hline M04 & $\begin{array}{l}\text { specialised museum-art } \\
\text { museum (government) }\end{array}$ & PR professional & Female \\
\hline M05 & general museum - (city) & marketing professional & Female \\
\hline
\end{tabular}

Source: Research

The sample consisted of five museum professionals. Two of them were from general museums and three from specialized museums (history, natural history and art museum). Three museums out of five were founded by the government while two are city-owned museums. Two respondents were marketing professionals, one PR professional, one 
ToSEE - Tourism in Southern and Eastern Europe, Vol. 5, pp. 375-387, 2019

T. Komarac, Đ. Ozretić Došen, V. Jurić Bulatović: THE ROLE OF SPECIAL EVENT IN ATTRACTING ...

museum curator and one museum educator. Four respondents were female, and one was male.

For the purpose of analyzing web and social media mentions of the "The Night of Museums" event in 2019, Mediatoolkit was used. Mediatoolkit is media monitoring and analytics tool that gathers information from millions of internet sources (including web and all social media platforms) (Mediatoolkit, 2019). Social media presence of "The Night of Museums" event was tracked using two official hashtags \#nocmuzeja and \#nocmuzeja2019 and analyzed in the period for more than one month (from $1^{\text {st }}$ January until $8^{\text {th }}$ February of 2019).

\section{RESULTS}

\subsection{Short descriptive summary of the results obtained in the first phase of the qualitative study (2013)}

Research results revealed museum professionals' opposite and divided opinions about "The Night of Museums" event.

Half of the respondents thought of "The Night of Museums" event as being more beneficial than costly for museums. The main advantage of the event was found to be its potential for attracting an interesting, non-usual audience. Furthermore, the appeal of the event was recognized as a trigger which helped museums to increase visitation, in several cases very much, even up to one-half of the total annual visits in one night.

Contrary, the other half of the respondents claimed that "The Night of Museums" was a very challenging task for museum professionals. They were faced with three major threats: control of crowds, the risk of damaging the exhibits, and lack of personnel i.e., problems related to the extended working hours. The event was very stressful for these respondents, even leading to the statement describing "The Night of Museums" as the hardest day in the life of a museum professional.

\subsection{Results of the second phase of the qualitative study conducted in 2018 and 2019}

All respondents agree that "The Night of Museums" event contributes to the popularization of museums, because "...it attracts more visitors, not only regular ones but also those that visit the museum from time to time" (M01). It is noticed that "Visitors feel more comfortable because they are not burdened with formalities (such as to be quiet and taking care of how they move around museums)" (M05).

Respondents believe that "The Night of Museums" has excellent advantages for museums, such as:

1. public visibility (M01, M02, M03, M04, M05)

2. popularization of museum visits (M01, M03, M04, M05)

3. attracting a new audience (M05). 
ToSEE - Tourism in Southern and Eastern Europe, Vol. 5, pp. 375-387, 2019

T. Komarac, Đ. Ozretić Došen, V. Jurić Bulatović: THE ROLE OF SPECIAL EVENT IN ATTRACTING ...

Furthermore, they point out that the organization of the event is very demanding and several disadvantages and sources of potential problems should be taken into consideration:

1. a mass audience in a short period that wants to "consume" museum experience (M01, M02, M03, M04)

2. a potential risk of damaging museum exhibits (M01, M04, M05)

3. some museums offer "inappropriate" content (M01)

4. lack of museum visitor's concentration and peace (M04)

5. lack of financial profitability for a museum (M04).

In comparison to everyday museum practice and service offer, special activities related to "The Night of Museums" include extended working hours (typically until 1 AM), specially created additional programs, mostly entertainment (M02, M04) and hospitality services (M02), but also informal gatherings. Some museums try to create a perfect balance between educational and entertainment contents, for example offering educational quizzes, music, and involving the local community in the program (M03).

The biggest challenge for museums in organizing "The Night of Museums" is to deliver a true museum experience. Four respondents (M01, M02, M04 and M05) are convinced that museums cannot deliver a true museum experience on that occasion, but they also stress that such an experience is not the goal of typical "The Night of Museums" visitor. One respondent believes that the problem with a true museum experience is more emphasized in larger cities (and museums) when they emphasize and promote fun for one night. Smaller towns have fewer problems in offering true experience (M03). Also, regular visitation is more formal than one during "The Night of Museums" event (M05).

Furthermore, some of the important and delicate aspects of the organization of "The Night of Museums" are related to:

1. securing museum exhibits (M01, M04, M05)

2. controlling crowds (M01)

3. counting visitors $(\mathrm{M} 01)$

4. hiring extra personnel (M03, M04)

5. management of small space (M03)

6. creating an appealing program (M01).

The organization of "The Night of Museums" does not represent a problem for one respondent only, because it has become a routine job (M02).

Although there is official statistical data about the number of museum visitors during "The Night of Museums" events, three respondents have stated that they conduct different kinds of additional monitoring and research during event in informal conversation with visitors (M05), after the event (M01, M03) and/or through the book of impression; while others do not conduct any kind of additional research (M02, M04). 
ToSEE - Tourism in Southern and Eastern Europe, Vol. 5, pp. 375-387, 2019

T. Komarac, Đ. Ozretić Došen, V. Jurić Bulatović: THE ROLE OF SPECIAL EVENT IN ATTRACTING ...

Respondents are convinced that "The Night of Museums" visitors expect different benefits from this special event, like:

1. having good fun (M01, M02, M03),

2. free entrance (M01, M04),

3. something different than in every-day museum visit (M01, M05),

4. a feeling of participation in something important (M02),

5. interactive and innovative content (M03),

6. new experience (M05).

Regarding the use of new technologies and social media in promoting special events like "The Night of Museums", respondents have expressed different opinions. Three respondents agree that new technologies and social media help in dissemination of information (M02, M03, M05), but also in attracting young visitors who are usually passive in choosing museums. One respondent has expressed reservation, due to the lack of research on the subject (M01). Only one respondent believes that new technologies and social media don't have an important role in increasing the number of museum visitors for "The Night of Museums" event (M04).

Respondents tend to track foreign museums' usual and special activities and have emphasized large differences existing regarding museums' resources. For example, one respondent (M01) stresses how in countries like the UK, museums similar in size to Croatian ones have much more museum educators than in Croatia - e.g., sixteen in the UK to only one or none in Croatia. Quite similar, two respondents (M03, M04) point out big differences and investments in foreign museums in technological equipment, which is lacking in Croatian museums. Most respondents use internet (web pages of foreign museums) for tracking their activities (M01, M03, M05).

\subsection{Results of social media mentions using two official hashtags}

Analysis of two official hashtags (\#nocmuzeja and \#nocmuzeja2019) using Mediatoolkit showed 440 mentions of the hashtag \#nocmuzeja and 396 mentions of the hashtag \#\#nocmuzeja2019, as well as their respective, very high number of total impressions (Table 2)

Table 2: Total number of mentions and impressions

\begin{tabular}{|l|c|c|}
\hline & Number of mentions & Total impressions \\
\hline \#nocmuzeja & 440 & 8323237 \\
\hline \#nocmuzeja2019 & 396 & 292971 \\
\hline
\end{tabular}

Source: Mediatoolkit

More detailed insight into hashtags usage revealed an increased number of mentions of both hashtags one day before the event (held on the 1st of February 2019), on the day of the event, and one day after the event (Graph 1 and 2). 
ToSEE - Tourism in Southern and Eastern Europe, Vol. 5, pp. 375-387, 2019

T. Komarac, Đ. Ozretić Došen, V. Jurić Bulatović: THE ROLE OF SPECIAL EVENT IN ATTRACTING ...

\section{Graph 1: Mentions over time by source (\#nocmuzeja)}

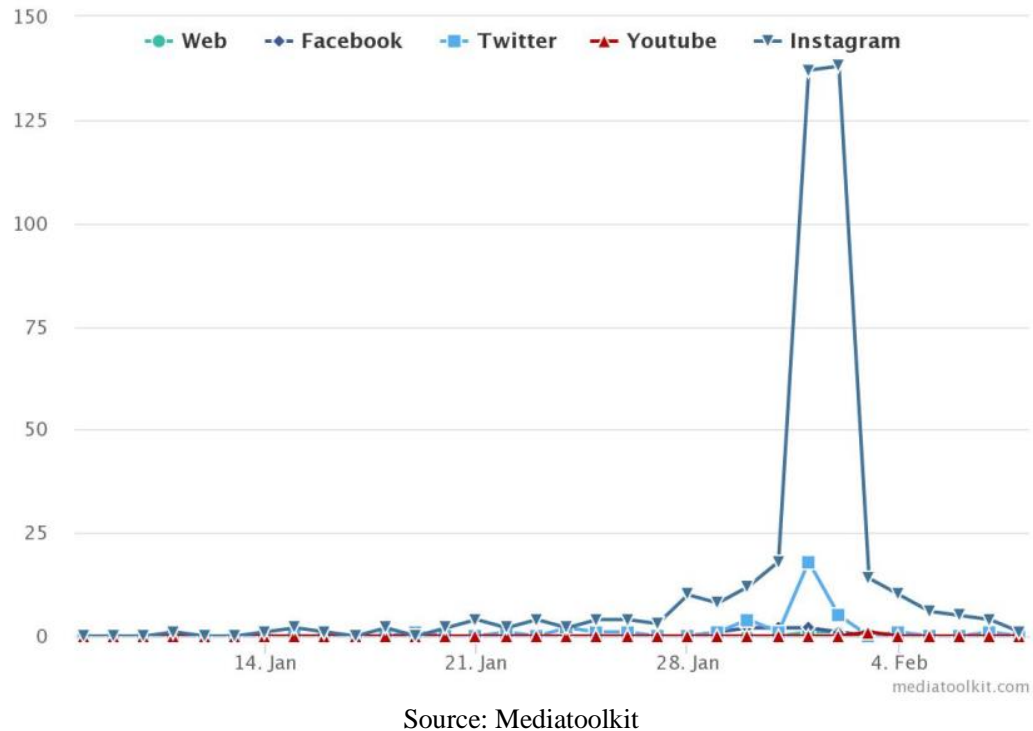

Graph 2: Mentions over time by source (\#nocmuzeja2019)

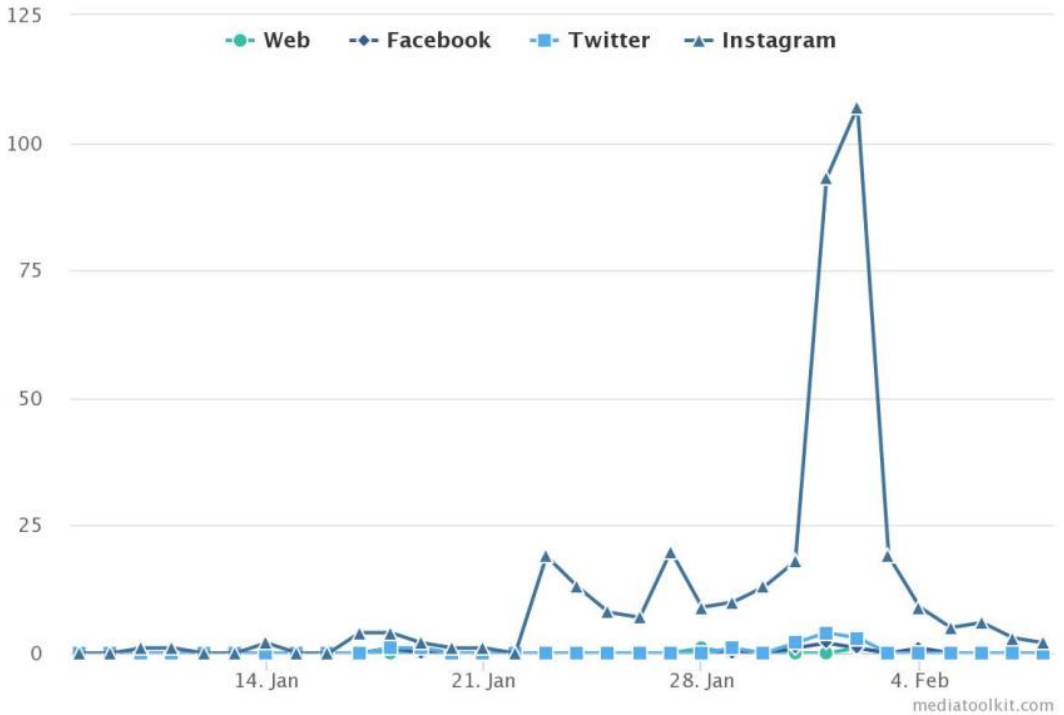

Source: Mediatoolkit

Both hashtags were predominantly used on Instagram: $89.09 \%$ for \#nocmuzeja and 94,96\% for \#nocmuzeja2019, signaling Instagrams' significance for "The Night of Museums" event. On other social media platforms, like Facebook and Twitter, these two hashtags were less present. 
ToSEE - Tourism in Southern and Eastern Europe, Vol. 5, pp. 375-387, 2019

T. Komarac, Đ. Ozretić Došen, V. Jurić Bulatović: THE ROLE OF SPECIAL EVENT IN ATTRACTING ...

Deeper insight into the type of sentiment (positive, negative or neutral) for both hashtags on different channels shows mostly neutral, followed by positive sentiment. Negative sentiment regarding the event is recorded on Instagram for \#nocmuzeja, and on Instagram and Twitter for \#nocmuzeja 2019, but with very small ratios (Graph 3 and 4)

Graph 3: Sentiment ratio by channel (for \#nocmuzeja)

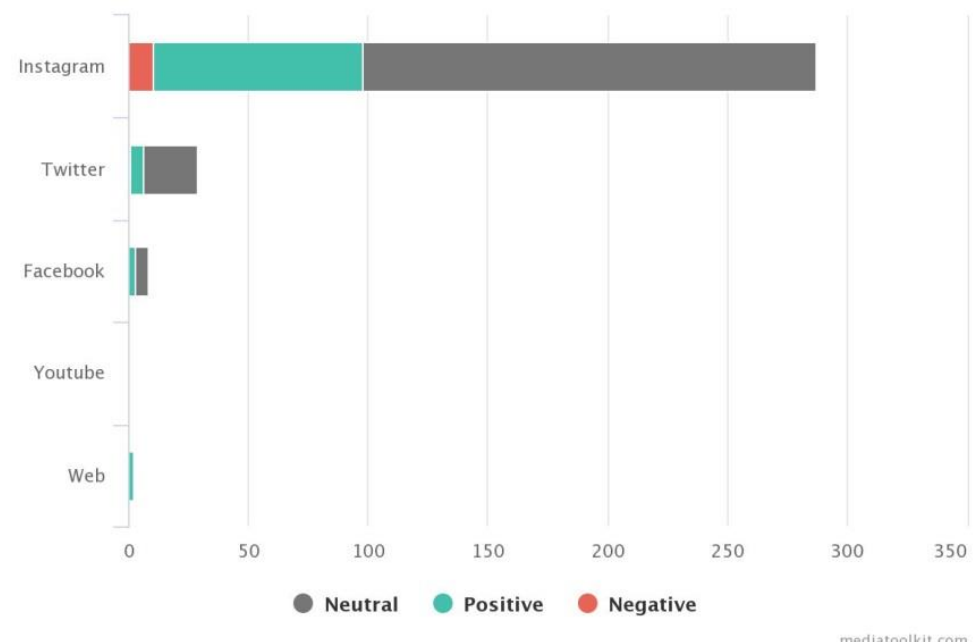

Source: Mediatoolkit

Graph 4: Sentiment ratio by channel (for \#nocmuzeja2019)

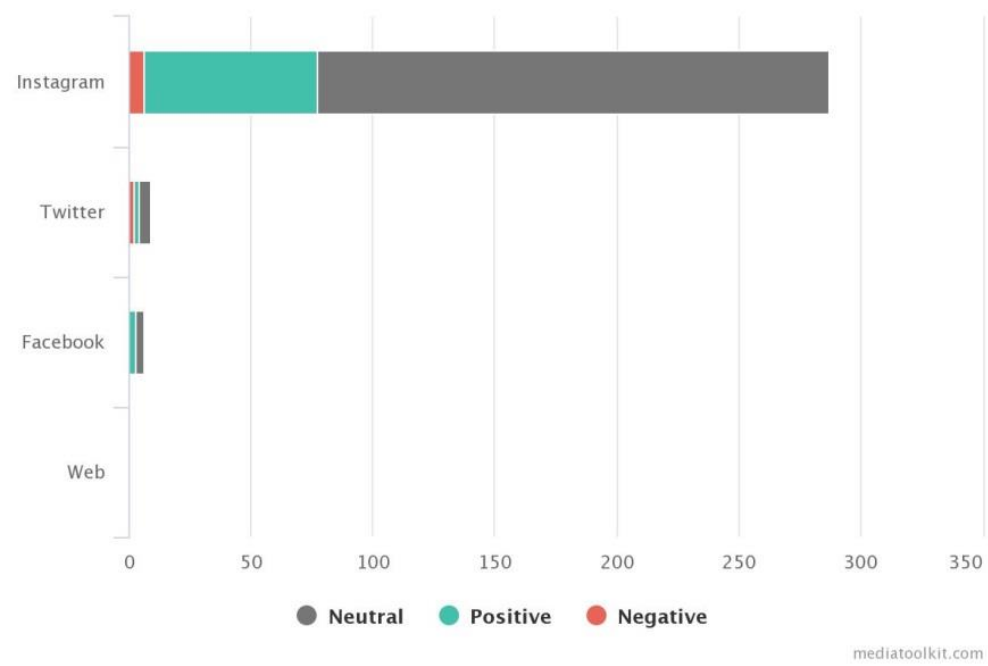

Source: Mediatoolkit

Results of mentions of the event "The Night of Museums" on social media (both for \#nocmuzeja and \#nocmuzeja2019) demonstrate popularity and importance of social media, predominantly Instagram, both for visitors and for organizers (museums). 
ToSEE - Tourism in Southern and Eastern Europe, Vol. 5, pp. 375-387, 2019

T. Komarac, Đ. Ozretić Došen, V. Jurić Bulatović: THE ROLE OF SPECIAL EVENT IN ATTRACTING ...

\section{LIMITATIONS}

Research limitations of the qualitative study are related primarily to the sample size and structure. The sample consisted of five experts (marketing and PR professionals, curator and educator). Researchers' subjectivity in the process of selection of questions, analysis, and interpretation of research results is also one limitation of the study. These limitations need to be considered in the interpretation of the results and offered conclusions.

\section{CONCLUSION}

The research results have revealed the perceived advantages of organizing special events (i.e. "The Night of Museums") that are mostly related to the popularization of museum visits, especially among a wider audience. This finding corroborates Axelsens' finding (2006) that special events are useful tool for attracting non-museum audience and wider audience.

While organizing "The Night of Museums" event museums face challenges regarding security concerns, physical limitations and personnel deficiency. In museum professionals' opinion, all these issues can lead to different and problematic consumption of museum experience. This finding extends on Gouding's proposal (2000) that crowding and noise create problems for museum management and museum visitors as well. On the other hand, there are respondents who believe that these same factors create a "special atmosphere" and higher interest among some type of audience (e.g., young visitors). This finding corroborates and extends Bjeljac et al.'s (2011) research conducted on museum visitors, which discovered that young visitors were attracted by entertainment and innovative museum offer.

Although museum professionals do not conduct formal market research during "The Night of Museums" event (because it would be "almost impossible"), they are aware of museum visitors' expectations (fun, free entrance, different experiences).

New technologies and social media are mostly used for communication and promoting events like "The Night of Museums" with the purpose of attracting young visitors. This is also shown through the result of social media and web mentions of two official hashtags. Surprisingly, Instagram is discovered to be the most important channel for twoway interaction. This finding partially corroborates and extends Lazzari et al.'s (2015) research that discovered the importance of social media for the promotion of special events.

A high number of visitors during "The Night of Museums" event shows an ongoing interest of a wider audience for visiting museums. However, keeping this interest is going to be one of the biggest challenges for museums in the future (slowly declining visitation in the last couple of years has been already recorded). Surely, without "The Night of Museums", annual number of museum visitors would be probably even lower and even more concerning. "The Night of Museums" event, therefore, represents an important part of museum offer aimed at attracting visitors and museum popularization. 
ToSEE - Tourism in Southern and Eastern Europe, Vol. 5, pp. 375-387, 2019

T. Komarac, Đ. Ozretić Došen, V. Jurić Bulatović: THE ROLE OF SPECIAL EVENT IN ATTRACTING ...

\section{REFERENCES}

Axelsen, M. (2006), "Using special events to motivate visitors to attend art galleries", Museum Management and Curatorship, Vol. 21, No. 3, pp. 205-221. doi: 10.1016/j.musmancur.2006.06.002

Bjeljac, Z., Brankov, J. and Lukić, V. (2011), "The Museum Night event - the demographic profile of the visitors in Serbia", Forum Geografic, Vol. 10, No. 2, pp. 229-234. doi: 10.5775/fg.2067-4635.2011.005.d

Croatian Museum Association Internal document (2012)

Dumbrăveanu, D., Tudoricu, A. and Crăciun, A. (2014), "The Night of Museums - A boost factor for the cultural dimension of tourism in Bucharest", Human Geographies - Journal of Studies and Research in Human Geography, Vol. 8, No. 1, pp. 55-63. doi: 10.5719/hgeo.2014.81.55

European Commission n.d., Special Eurobarometer 466 Report - Cultural Heritage viewed $29^{\text {th }}$ November 2018, https://europa.eu/cultural-heritage/toolkits/special-eurobarometer-europeans-and-culturalheritage_en.

Evans, G. (2012), "Hold back the night: Nuit Blanche and all-night events in capital cities", Current Issues in Tourism, Vol. 15, No. 2, pp. 35-49. doi: 10.1080/13683500.2011.634893

Fletcher, A. and Lee, M.J. (2012), "Current social media uses and evaluations in American museums", Museum Management and Curatorship, Vol. 27, No. 5, pp. 501-525. doi: 10.1080/09647775.2012.738136

Germain, F. (2016), "Visiting museum at night: A decidedly different experience", Loisir et Société / Society and Leisure, Vol. 39, No. 3, pp. 433-450. doi: 10.1080/07053436.2016.1244146

Getz, D. (2008), "Event tourism: Definition, evolution, and research", Tourism Management, Vol. 29, No. 3 , pp. 403-428. doi: 10.1016/j.tourman.2007.07.017

Goulding, C. (2000), "The museum environment and the visitor experience", European Journal of Marketing, Vol, 34, No. 3/4, pp. 261-278. doi: 10.1108/03090560010311849

Hrvatsko muzejsko društvo, n.d., Noć Muzeja, viewed on $2^{\text {nd }}$ January 2019, http://hrmud.hr/noc-muzeja/

Hill, L., O'Sullivan, C., O'Sullivan, T. and Whitehead, B. (2018), Creative arts marketing, $3^{\text {rd }}$ Edition, Routledge, Abringdon, UK.

Jaremen, D.E. and Rapacz, A. (2018), "Cultural events as a method for creating a new future for museums", Turyzm/Tourism, Vol. 28, No. 1, pp. 25-33. doi: 10.18778/0867-5856.28.1.11

Komarac, T., Ozretić Došen, Đ. and Škare, V. (2017), "Understanding competition and service offer in museum marketing”, Academia Revista Latinoamericana de Administración, Vol. 30, No. 2, pp. 215-230. doi: 10.1108/ARLA-07-2015-0159

Lazzeretti, L., Sartori, A. and Innocenti, N. (2015), "Museums and social media: the case of the Museum of Natural History of Florence", International Review on Public and Nonprofit Marketing, Vol. 12, No. 3, pp. 267-283. doi: 10.1007/s12208-015-0136-5

Matthews, D. (2008), Special Events Production: The Process, Butterworth-Heinemann, Oxford.

Mavrin, I. and Glavaš, J. (2014), "The Night of the Museums event and developing new museum audience Facts and misapprehensions on a cultural event", Interdisciplinary Management Research, pp. 265274.

Mediatoolkit, About Us viewed on $28^{\text {th }}$ January 2019, https://www.mediatoolkit.com/about-us

Noć muzeja n.d., O nama viewed on $20^{\text {th }}$ December 2018, http://nocmuzeja.hr/o-nama 
ToSEE - Tourism in Southern and Eastern Europe, Vol. 5, pp. 375-387, 2019

T. Komarac, Đ. Ozretić Došen, V. Jurić Bulatović: THE ROLE OF SPECIAL EVENT IN ATTRACTING ...

Tanja Komarac, PhD, Teaching and Research Assistant

University of Zagreb

Faculty of Economics \& Business

Marketing Department

Trg J. F. Kennedyja 6, 10000 Zagreb, Croatia

Phone: +385-12-383302

E-mail: tkomarac@efzg.hr

Đurđana Ozretić Došen, $\mathrm{PhD}$, Full Professor

University of Zagreb

Faculty of Economics \& Business

Marketing Department

Trg J. F. Kennedyja 6, 10000 Zagreb, Croatia

Phone: +385-12-383463

E-mail: dozretic@efzg.hr

Vesna Jurić Bulatović, MSc, Head of Marketing and PR Department

Museum of Arts and Crafts

Trg Republike Hrvatske 10, 10000 Zagreb, Croatia

Phone: +385-14-882123

E-mail: vesna.juric.bulatovic@ muo.hr 